\title{
Soil carbon and nitrogen sequestration and crop growth as influenced by long-term application of effective microorganism compost
}

\author{
Cheng $\mathrm{Hu}^{1}$, Xiange $\mathrm{Xia}^{1}$, Yunfeng Chen ${ }^{1}$, and Xuemei Han ${ }^{2 *}$ \\ ${ }^{1}$ Hubei Academy of Agricultural Sciences, Institute of Plant Protection and Soil Fertilizer, Wuhan 430064, P.R. China. \\ ${ }^{2}$ Nanyang Normal University, School of Life Science and Technology, Nanyang, 473061, P.R. China. \\ *Corresponding author (hanxuemei916@163.com).
}

Received: 15 July 2017; Accepted: 13 October 2017; doi:10.4067/S0718-58392018000100013

\section{ABSTRACT}

Long-term excessive application of inorganic fertilizers not only wastes resources but also contaminates the environment. The use of natural substitutes could overcome these drawbacks. We hypothesize that organic fertilizers could increase soil $\mathrm{C}, \mathrm{N}$ sequestration and improve soil fertility more effectively than inorganic fertilizers, and that in particular effective microorganism (EM) could improve the effects of traditional compost. So, a long-term field experiment regarding improvement of soil fertility, protecting soil environment, and increasing of maize and wheat yield was conducted at China Agricultural University's Qu-Zhou experiment station since 1993. Field experiment included EM compost treatment, traditional compost treatment, chemical fertilizer treatment, and unfertilized treatment. Soil organic C (SOC), total N, nutrient concentrations, pH, bulk density, and crop yields were determined. The results revealed that long-term repeated application of EM compost promoted soil $\mathrm{C}$ and $\mathrm{N}$ sequestration, increased soil nutrient contents, decreased soil $\mathrm{pH}$ and bulk density, enhanced crop yields in contrast to chemical fertilizer and control treatment. Soil organic C stocks $(0-20 \mathrm{~cm})$ were increased by $87.32 \%, 81.51 \%, 33.05 \%$, $25.20 \%$ and soil total $\mathrm{N}$ stocks were increased by $93.26 \%, 77.53 \%, 37.64 \%, 34.83 \%$ in contrast to initial values in EM compost, traditional compost, chemical fertilizer and control treatments, respectively. Moreover, maize grain yields in EM compost, traditional compost, and chemical fertilizer treatments were significantly increased by $163.49 \%, 128.34 \%, 62.36 \%$ compared with control treatment, respectively. The effect of increased soil C and $\mathrm{N}$ sequestration, improving soil fertility and enhanced crop yields in application of compost appending EM was better than alone application of compost.

Key words: Compost, effective microorganism, sequestration, soil organic carbon, total nitrogen.

\section{INTRODUCTION}

Soil organic C (SOC) plays a vital role with respect to soil physical, chemical and biological properties, and whole soil fertility. At the same time, increased soil $\mathrm{C}$ concentration revealed a potential sink of atmospheric $\mathrm{CO}_{2}$ in arable farmland. Soil $\mathrm{C}$ sequestration in croplands is not only to increase soil $\mathrm{C}$ storage for $\mathrm{C}$ trade and mitigate $\mathrm{CO}_{2}$ emission, but also to improve soil fertility and enhance crop production. Similarly, $\mathrm{N}$ sequestration could reduce the amount of $\mathrm{N}$ fertilization, $\mathrm{N}$ leaching, and $\mathrm{N}_{2} \mathrm{O}$ emission, another destructive greenhouse gas causing global warming, and increased plant-available N content (Sainju et al., 2008). So, keeping perfect soil $\mathrm{C}$ and $\mathrm{N}$ concentration is important in order to maintaining soil fertility and sustaining agriculture productivity. The enhanced SOC and N concentration in cropland availed both soil productivity and environmental quality. Soil C, N sequestration is generally affected by many factors, 
such as fertilization, crop rotation, tillage, land use and climate. Some studies indicated that application of fertilization, conservation tillage, crop cover could increase soil C and N stocks (Sainju et al., 2008). For example, long-term application of inorganic and organic fertilizers could increase soil $\mathrm{C}$ and $\mathrm{N}$ sequestration in a rice-wheat cropping system (Shen et al., 2007) and in a rotation system of winter wheat and summer maize (Chu et al., 2007). Nevertheless, some reports only observed that long-term application of manure could increase soil $\mathrm{C}$ and $\mathrm{N}$ stock and long-term application of inorganic fertilizer alone decreased SOC concentration in arid northwestern China ( $\mathrm{Su}$ et al., 2006) or decreased soil total $\mathrm{N}$ concentration in a semiarid cropland (Zhou et al., 2013). Those data are of crucial importance for accurate estimation of soil C sequestration potential in the present conditions and for elucidating the role of China's farmland in global climate change (Shen et al., 2007).

Summer maize (Zea mays L.) is one of the staple food crops in the North China Plain, and its cultivated area and total grain production was one third of the Chinese crop. The North China Plain covers an area of $178700 \mathrm{~km}^{2}$, of which 50\% is cultivated cropland. The North China Plain is the largest and most important agriculture regions of China and mainly produced by cereal crop. Winter wheat (Triticum aestivum L.) and summer maize (JuneSeptember) rotation is the most important agricultural production system in this region, accounting for $61 \%$ and $33 \%$ of the nation's annual production of wheat and maize, respectively. In the past, Chinese farmers use farmyard manure, green manure or crop straw to maintain soil fertility. However, with the rapid development of economy, synthetic fertilizers were largely and widely applied in China since 1980s (Gong et al., 2011). In 1998, the total annual quantity of fertilizers applied in the country reached 41 million tons. As a result, China is now the world's largest consumer of chemical fertilizers. Chemical fertilizer was excessively and unreasonably applied in order to achieve the maximum of crop yields, not only wasting resource, but also contaminating environment. Thus, reasonable and optimal application fertilizer, improving soil fertility and quality, ensuring China's food security, and protecting the environment are crucial in this region.

Higa (1991) isolated some beneficial microorganism from the soil and called them effective microorganism (EM). Effective microorganism contains about 80 species of microorganisms, which included photosynthetic bacteria, lactic acid bacteria, yeasts, actinomycetes, and fermenting fungi like Aspergillus and Penicillium. Application of effective microorganism could promote crop growth and increase crop yield, and accelerate decomposition of organic materials in the soil. There had some reports about effect of EM application on crop growth, such as peanut, cotton, banana, chard, pea, soybean, rice, vigna, mung-bean, wheat (Javaid and Bajwa, 2011a; 2011b). However, there were a few investigations on the effect of long-term repeated application of EM on soil C, N sequestration and crop growth. Long-term field experiments were valuable information repositories about sustainable agriculture and provided opportunities for monitoring long-term changes about soil productivity, soil fertility and soil environment.

Therefore, we carried out an $11 \mathrm{yr}$ fertilizer experiment to study effect of long-term application of EM and compost on soil C, $\mathrm{N}$ sequestration and crop growth. The results could reveal the effect of long-term EM application on soil $\mathrm{C}, \mathrm{N}$ sequestration and maize yield, and help the selection of the optimal fertilization mode for maintaining high soil productivity, and protecting soil environment.

\section{MATERIALS AND METHODS}

\section{Study site and experiment design}

The experiment site was situated at China Agricultural University's Qu-Zhou experimental station ( $\left(115^{\circ} 01^{\prime} \mathrm{E}\right.$, $36^{\circ} 52^{\prime} \mathrm{N}$ ) in North China Plain. The climate in this experimental station is warm, semi-humid and has rainy summers and dry, cold winters. The mean annual temperature is $13.2^{\circ} \mathrm{C}$ and ranges from a minimum of $-2.9^{\circ} \mathrm{C}$ in January to a maximum of $26.8{ }^{\circ} \mathrm{C}$ in July. The mean annual precipitation is $542.7 \mathrm{~mm}$, of which $60 \%$ occurs from July to September, and the annual non-frost period is $201 \mathrm{~d}$. The soil at study site is an Aquic Cambisol according to the FAO.

The on-going long-term fertilizer experiment was designed with four treatments, laid out in a randomized complete block design, with each plot $4 \times 8 \mathrm{~m}$ in size. The field included the following four treatments: effective 
microorganism compost treatment (EM, $\left.15 \mathrm{t} \mathrm{ha}^{-1}\right)$; traditional compost treatment (TC, $15 \mathrm{t} \mathrm{ha}^{-1}$ ); $\mathrm{N}$ and $\mathrm{P}$ fertilizer treatment ( $\mathrm{CF}, 265.5 \mathrm{~kg} \mathrm{~N} \mathrm{ha}^{-1}$ and $90 \mathrm{~kg} \mathrm{P}_{2} \mathrm{O}_{5} \mathrm{ha}^{-1}$ ), and control, unfertilized treatment. The traditional compost was $60 \%$ crop straw, $30 \%$ livestock dung, 5\% cottonseed-pressed trash, and 5\% bran (a mean nutrient content: $100.5 \mathrm{~kg} \mathrm{~N} \mathrm{ha}^{-1}, 36 \mathrm{~kg} \mathrm{P}_{2} \mathrm{O}_{5} \mathrm{ha}^{-1}$, and $196.2 \mathrm{~kg} \mathrm{~K}_{2} \mathrm{O} \mathrm{ha}^{-1}$ ). Every $50 \mathrm{~kg}$ of EM compost consisted of $50 \mathrm{~kg}$ traditional compost appended with $200 \mathrm{~mL}$ concentrated EM; $1 \mathrm{~mL}$ of EM concentrate contained a minimum of $10^{5}$ viable organisms of Streptomyces albus, Propionibacterium freudenreichii, Streptococcus lactis, Aspergillus oryzae, Mucor hiemalis, Saccharomyces cerevisiae, and Candida utilis, in addition to an unspecified number of Lactobacillus sp., Rhodopseudomonas sp., and Streptomyces griseus. Nitrogen fertilizer used was $48 \%$ ammonium bicarbonate (17\% $\mathrm{N})$ and $52 \%$ urea $(46 \% \mathrm{~N})$; P fertilizer used was calcium super-phosphate $\left(12 \% \mathrm{P}_{2} \mathrm{O}_{5}\right)$.

Compost or chemical fertilizer twice were applied as basal fertilizers annually, just before the planting of summer maize and winter wheat, and the amount of fertilizer was uniform in maize and wheat crop. All compost and chemical fertilizer were evenly spread into the soil surface by hand and immediately incorporated into the plough layer by tillage before sowing maize or wheat. Tillage was done to $20 \mathrm{~cm}$ depth by plough and followed by harrow. The fertilized and unfertilized plots were the same type of tilth. Neither compost nor chemical fertilizer was applied during maize and wheat growth stages. The fertilizer types, rates and times of application were typical for this region. Experimental field were cultivated with maize (Zea mays L.) in summer and with wheat (Triticum aestivum L.) in winter at the beginning of 1993, which is the typical planting mode in this region. The maize was sowed with direct seeding in June and harvested in October, followed by wheat, which was cultivated in October and harvested in June next year. The aboveground crop was reaped, and no straw was returned to incorporate into soil. However, maize or wheat stubble and root was incorporated into the soil with plow before planting wheat or maize. Besides fertilizer of application, all the other agronomic practice was identical. The total amount of $\mathrm{C}, \mathrm{N}, \mathrm{P}$, and $\mathrm{K}$ input to the soil in all the four treatments through fertilization every year were showed in Table 1.

Table 1. Total amount of $\mathrm{C}, \mathrm{N}, \mathrm{P}$, and $\mathrm{K}$ input to the soil through fertilization in all treatments every year.

\begin{tabular}{lrrrr}
\hline Treatment & $\mathrm{C}$ & $\mathrm{N}$ & $\mathrm{P}$ & \multicolumn{1}{c}{$\mathrm{K}$} \\
\cline { 2 - 5 } & & & & \\
\cline { 2 - 5 } $\mathrm{kg} \mathrm{ha}^{-1}$ & & & \\
\cline { 2 - 4 } Control & 0 & 0 & 78.59 & 0.00 \\
CF & 0 & 531 & 31.44 & 0.00 \\
TC & 6840 & 201 & 31.44 & 325.61 \\
EM & 6840 & 201 & 325.61 \\
\hline
\end{tabular}

Control: Unfertilized treatment; CF: chemical fertilizer treatment; TC: traditional compost treatment; EM: effective microorganism compost treatment.

\section{Soil sampling and analysis}

Initial soil samples were collected in 1993 prior to the start of the experiment. After $11 \mathrm{yr}$ field experiments, soil samples were collected from the $0-20 \mathrm{~cm}$ soil layer at each experiment plots, using a $2.5 \mathrm{~cm}$ diameter soil auger before maize planting on 8 June 2004. Each soil sample consisted of 15 cores $(2.5 \mathrm{~cm}$ diameter $)$, which were mixed to form a composite sample. The soil samples were stored in insulated and tied plastic bags and transported to the laboratory.

Soil bulk density was determined using the core volume and dry soil weight. Soil sub-samples were air-dried for $14 \mathrm{~d}$ at room temperature, sieved through a $1 \mathrm{~mm}$ screen, mixed, and sub-samples were used to analyze for available $\mathrm{N}$, available $\mathrm{P}$, available $\mathrm{K}$ and soil $\mathrm{pH}$. The air-dried sub-samples were ground to pass through a 0.25 $\mathrm{mm}$ sieve to determine SOC and total $\mathrm{N}$ content. The potassium dichromate external heating method was applied to determine SOC content. The semi-micro Kjeldahl method and the alkaline-hydrolyzable diffusion method were applied to determine total $\mathrm{N}$ and available $\mathrm{N}$ content. Soil available $\mathrm{P}$ was extracted with $0.5 \mathrm{~mol} \mathrm{NaHCO}_{3} \mathrm{~L}^{-1}$ (soil:solution 1:20) and measured with the Olsen method. Soil available K was extracted with $1 \mathrm{~mol} \mathrm{NH}_{4} \mathrm{Ac} \mathrm{L}^{-1}$ (soil:solution 1:10) and measured with the flame photometry method. Soil pH was measured in $0.01 \mathrm{~mol} \mathrm{CaCl}_{2} \mathrm{~L}^{-1}$ slurry (soil:solution 1:2.5) using a glass electrode. 


\section{Crop harvesting}

Maize cob was harvested by hand on 8 October 2004. Cornstalk was reaped and removed from plots. Maize cob was dried by sun and grains were separated from cob using thresher. Maize grain yields were weighted after sun-drying and were recorded from a whole plot. Twenty maize cobs were used to evaluate agronomic character of corn. All the data were expressed on dry mass basis.

\section{Calculation of soil $\mathrm{C}, \mathrm{N}$ stock and sequestration}

Soil organic $\mathrm{C}$ and total $\mathrm{N}$ stock were calculated by multiplying SOC or total $\mathrm{N}$ concentrations by bulk density and depth. The amount of sequestered organic $\mathrm{C}$ and total $\mathrm{N}$ in 0-20 $\mathrm{cm}$ soil depth in every treatment was estimated after subtracting the initial SOC and total N stocks.

\section{Statistical analysis}

All obtained data were subjected to ANOVA using the SPSS 11.5 software package (IBM, Armonk, New York, USA) and were used to evaluate differences between treatments. Difference obtained at $P<0.05$ level was considered as significant using the least significant difference (LSD) test. Pearson linear correlation (two tailed) was used to evaluate the relationships between the parameters.

\section{RESULTS}

\section{Soil organic $\mathrm{C}$ and total $\mathrm{N}$ concentration and stock}

The content of SOC and total $\mathrm{N}$ through $11 \mathrm{yr}$ field experiment (including control) was increased by $28.18 \%$ $112.54 \%$ and $37.29 \%-118.64 \%$ contrasted to the initial values, respectively. The highest contents of SOC and total $\mathrm{N}$ were found in the EM compost treatment and the lowest values were found in the control treatment after $11 \mathrm{yr}$ experiments. Application of compost significantly $(P<0.05)$ increased SOC and total $\mathrm{N}$ contents in contrast to chemical fertilizer and control treatments. The content of SOC and total $\mathrm{N}$ due to $11 \mathrm{yr}$ fertilizer application was increased by $6.57 \%-65.82 \%$ and $2.47 \%-59.26 \%$ in comparison to control, respectively (Table 2 ).

Soil organic $\mathrm{C}$ stock, sequestration and sequestration rate in two compost treatments were significantly $(P<0.05)$ higher than in the chemical fertilizer and control treatments. Soil total $\mathrm{N}$ stock, sequestration and sequestration rate in two compost treatments were significantly $(P<0.05)$ higher than in the chemical fertilizer and control treatments (Table 3).

\section{Soil nutrients, soil pH and bulk density}

The content of available $\mathrm{N}$ and available $\mathrm{K}$ through $11 \mathrm{yr}$ field experiment (including control) were increased by $5.90 \%-73.29 \%$ and $11.43 \%-216.98 \%$ in contrast to the initial values, respectively. The content of available $\mathrm{P}$ through $11 \mathrm{yr}$ field experiment in the control treatments were significantly $(P<0.05)$ decreased by $84.42 \%$ in contrast to the initial values. The highest contents of soil available $\mathrm{N}$, available $\mathrm{P}$ and available $\mathrm{K}$ were observed in the EM compost treatment and the lowest values in the control treatment after $11 \mathrm{yr}$ field experiment. The content of available $\mathrm{N}$ and available $\mathrm{K}$ in two compost treatments were significantly $(P<0.05)$ higher than

Table 2. Some soil physical-chemical properties in long-term fertilization experiment (1993-2004).

\begin{tabular}{|c|c|c|c|c|c|c|c|c|}
\hline Treatment & $\begin{array}{c}\text { Soil } \\
\text { organic C }\end{array}$ & $\underset{\mathrm{N}}{\text { Total }}$ & $\mathrm{C} / \mathrm{N}$ & $\underset{N}{\text { Available }}$ & $\begin{array}{c}\text { Available } \\
\text { P }\end{array}$ & $\underset{\mathrm{k}}{\text { Available }}$ & $\mathrm{pH}$ & $\begin{array}{c}\text { Bulk } \\
\text { density }\end{array}$ \\
\hline & \multicolumn{2}{|c|}{$\mathrm{g} \mathrm{kg}^{-1}$} & & . & $\mathrm{mg} \mathrm{kg}^{-1}$ & . & & $\mathrm{g} \mathrm{cm}^{-3}$ \\
\hline Initial values & $5.82 \mathrm{c}$ & $0.59 \mathrm{c}$ & $9.86 \mathrm{a}$ & $64.62 b$ & $26.13 b$ & $65.37 c$ & $8.77 \mathrm{a}$ & $1.51 \mathrm{a}$ \\
\hline Control & $7.46 b$ & $0.81 b$ & $9.17 \mathrm{a}$ & $68.43 b$ & $4.07 \mathrm{c}$ & $80.86 c$ & $7.53 b$ & $1.47 \mathrm{a}$ \\
\hline $\mathrm{CF}$ & $7.95 b$ & $0.83 b$ & $9.58 \mathrm{a}$ & $68.93 b$ & $23.63 b$ & $72.84 \mathrm{c}$ & $7.41 \mathrm{c}$ & $1.47 \mathrm{a}$ \\
\hline $\mathrm{TC}$ & $12.10 \mathrm{a}$ & $1.20 \mathrm{a}$ & $10.12 \mathrm{a}$ & $103.71 \mathrm{a}$ & $36.29 b$ & $161.75 b$ & $7.26 \mathrm{~d}$ & $1.32 \mathrm{~b}$ \\
\hline EM & $12.37 \mathrm{a}$ & $1.29 \mathrm{a}$ & $9.56 \mathrm{a}$ & 111.98a & $50.69 a$ & $207.21 \mathrm{a}$ & $7.15 \mathrm{e}$ & $1.33 b$ \\
\hline
\end{tabular}

Control: Unfertilized treatment; CF: chemical fertilizer treatment; TC: traditional compost treatment; EM: effective microorganism compost treatment.

Different letters indicate significant differences $(P<0.05)$ between treatments according to LSD multiple comparison. 
Table 3. Soil organic C (SOC), total N stock and sequestration in long-term fertilization experiment after 11 yr of different fertilization treatments.

\begin{tabular}{|c|c|c|c|c|c|c|}
\hline Treatment & $\begin{array}{l}\text { SOC } \\
\text { stock }\end{array}$ & $\begin{array}{c}\text { SOC } \\
\text { sequestration }\end{array}$ & $\begin{array}{l}\text { SOC sequestration } \\
\text { rate }\end{array}$ & $\begin{array}{l}\mathrm{N} \\
\text { stock }\end{array}$ & $\begin{array}{c}\mathrm{N} \\
\text { sequestration }\end{array}$ & $\begin{array}{l}\mathrm{N} \text { sequestration } \\
\text { rate }\end{array}$ \\
\hline & 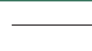 & $\mathrm{a}^{-1}$ & $\mathrm{tha}^{-1} \mathrm{yr}^{-1}$ & 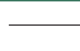 & $a^{-1}$ & $\mathrm{~kg} \mathrm{ha}^{-1} \mathrm{yr}^{-1}$ \\
\hline Initial values & $17.58 \mathrm{c}$ & - & - & $1.78 \mathrm{c}$ & - & - \\
\hline Control & $22.01 \mathrm{~b}$ & $4.43 b$ & $0.40 \mathrm{~b}$ & $2.40 \mathrm{~b}$ & $0.62 b$ & $56.04 \mathrm{~b}$ \\
\hline $\mathrm{CF}$ & $23.39 b$ & $5.81 \mathrm{~b}$ & $0.53 b$ & $2.45 b$ & $0.67 b$ & $60.89 b$ \\
\hline $\mathrm{TC}$ & $31.91 \mathrm{a}$ & $14.33 \mathrm{a}$ & $1.30 \mathrm{a}$ & $3.16 \mathrm{a}$ & $1.38 \mathrm{a}$ & $125.07 \mathrm{a}$ \\
\hline EM & $32.93 \mathrm{a}$ & $15.35 \mathrm{a}$ & $1.40 \mathrm{a}$ & $3.44 \mathrm{a}$ & $1.66 \mathrm{a}$ & $151.23 \mathrm{a}$ \\
\hline
\end{tabular}

Control: Unfertilized treatment; CF: chemical fertilizer treatment; TC: traditional compost treatment; EM: effective microorganism compost treatment.

Different letters indicate significant differences $(P<0.05)$ between treatments according to LSD multiple comparison.

in the chemical fertilizer and control treatments, and the content of available $\mathrm{P}$ in the fertilization treatments significantly $(P<0.05)$ higher than in the control treatment. The content of available $\mathrm{P}$ and available $\mathrm{K}$ in the EM compost treatment was significantly $(P<0.05)$ increased by $39.68 \%$ and $28.11 \%$ than in the traditional compost treatment, respectively (Table 2).

Soil $\mathrm{pH}$ and bulk density through $11 \mathrm{yr}$ field experiment (including control) were decreased by 14.14\%-18.47\% and $2.65 \%-12.58 \%$ in comparison with the initial values, respectively. Soil $\mathrm{pH}$ in the fertilization treatment was significantly $(P<0.05)$ decreased by $1.59 \%-5.05 \%$ in contrast to control treatment. Soil $\mathrm{pH}$ in the fertilization treatments were significantly $(P<0.05)$ lower than in the control treatment, and were significantly $(P<0.05)$ lower in the compost treatments than in the chemical fertilizer treatment, and were significantly $(P<0.05)$ lower in the EM compost treatment than in the traditional compost treatment. Soil bulk density was significantly $(P<0.05)$ lower in the compost treatments than in the chemical fertilizer and control treatments (Table 2).

\section{Maize grain yields and yield components}

Maize plant height, spike length, spike width, line number per spike, grain number per line, grain number per spike, grain weight per spike, 1000-grains weight, and grain yields in the fertilization treatments were $16.38 \%$ $20.87 \%, 22.49 \%-52.99 \%, 8.37 \%-17.04 \%, 11.19 \%-20.48 \%, 27.83 \%-68.43 \%, 41.57 \%-102.14 \%, 79.42 \%-154.22 \%$, 14.47\%-30.09\%, and 62.36\%-163.49\% increased compared with the control treatment. Spike length, grain number per spike, grain weight per spike, 1000-grains weight, and grain yields of maize in the EM compost treatment were significantly $(P<0.05)$ increased by $10.34 \%, 9.98 \%, 15.02 \%, 4.96 \%, 15.39 \%$ in contrast to the traditional compost treatment, respectively. Spike length, gain number per spike, gain weight per spike, 1000 -grains weight, and grain yields of maize in the fertilization treatments were significantly $(P<0.05)$ higher than in the control treatment, and were significantly $(P<0.05)$ higher in two compost treatments than in the chemical fertilizer treatment. Plant height, spike width, line number per spike, and grain number per line in the fertilization treatments were significantly $(P<0.05)$ higher than in the control treatment, and spike width, grain number per line in two compost treatments were significantly $(P<0.05)$ higher than in the chemical fertilizer treatment (Table 4$)$.

Table 4. Maize grain yields and yields components in long-term fertilization experiment in 2004.

\begin{tabular}{|c|c|c|c|c|c|c|c|c|c|}
\hline Treatment & $\begin{array}{l}\text { Plant } \\
\text { height }\end{array}$ & $\begin{array}{l}\text { Spike } \\
\text { length }\end{array}$ & $\begin{array}{l}\text { Spike } \\
\text { width }\end{array}$ & $\begin{array}{c}\text { Line } \\
\text { number } \\
\text { spike }^{-1}\end{array}$ & $\begin{array}{l}\text { Grain } \\
\text { number } \\
\text { line }^{-1}\end{array}$ & $\begin{array}{c}\text { Grain } \\
\text { number } \\
\text { spike }^{-1}\end{array}$ & $\begin{array}{l}\text { Grain } \\
\text { weight } \\
\text { spike }^{-1}\end{array}$ & $\begin{array}{c}\text { 1000-grains } \\
\text { weight }\end{array}$ & $\begin{array}{l}\text { Grain } \\
\text { yields }\end{array}$ \\
\hline & 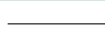 & $\mathrm{cm}$ & - & & & & & 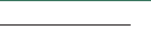 & $\mathrm{tha}^{-1}$ \\
\hline Control & $230.00 \mathrm{~b}$ & $14.23 \mathrm{~d}$ & $13.50 \mathrm{c}$ & $13.67 \mathrm{c}$ & $23.57 \mathrm{c}$ & $323.42 \mathrm{~d}$ & $79.33 d$ & $260.33 d$ & $4.41 \mathrm{~d}$ \\
\hline $\mathrm{CF}$ & $267.67 \mathrm{a}$ & $17.43 \mathrm{c}$ & $14.63 b$ & $15.20 \mathrm{~b}$ & $30.13 b$ & $457.87 \mathrm{c}$ & $142.33 c$ & $298.00 \mathrm{c}$ & $7.16 \mathrm{c}$ \\
\hline TC & $274.67 \mathrm{a}$ & $19.73 b$ & $15.57 \mathrm{a}$ & 16.07ab & $37.00 \mathrm{a}$ & $594.40 \mathrm{~b}$ & $175.33 b$ & $322.67 b$ & $10.07 \mathrm{~b}$ \\
\hline EM & $278.00 \mathrm{a}$ & $21.77 \mathrm{a}$ & $15.80 \mathrm{a}$ & $16.47 \mathrm{a}$ & $39.70 \mathrm{a}$ & $653.75 \mathrm{a}$ & $201.67 \mathrm{a}$ & $338.67 \mathrm{a}$ & $11.62 \mathrm{a}$ \\
\hline
\end{tabular}

Control: Unfertilized treatment; CF: chemical fertilizer treatment; TC: traditional compost treatment; EM: effective microorganism compost treatment.

Different letters indicate significant differences $(P<0.05)$ between treatments according to LSD multiple comparison. 


\section{Correlation analysis}

A significantly positive regression relationship could be established between SOC sequestration rate and grain yields of maize. Similarly, soil $\mathrm{N}$ sequestration rate was significantly positively correlated with grain yields of maize (Figures 1 and 2).

Figure 1. Regression relationship between soil organic $\mathrm{C}$ sequestration rate and grain yields of maize.

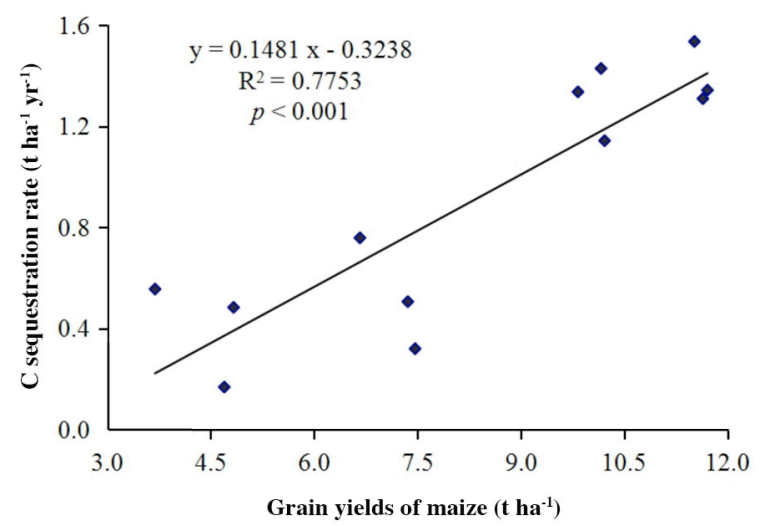

Figure 2. Regression relationship between soil $\mathbf{N}$ sequestration rate and grain yields of maize.

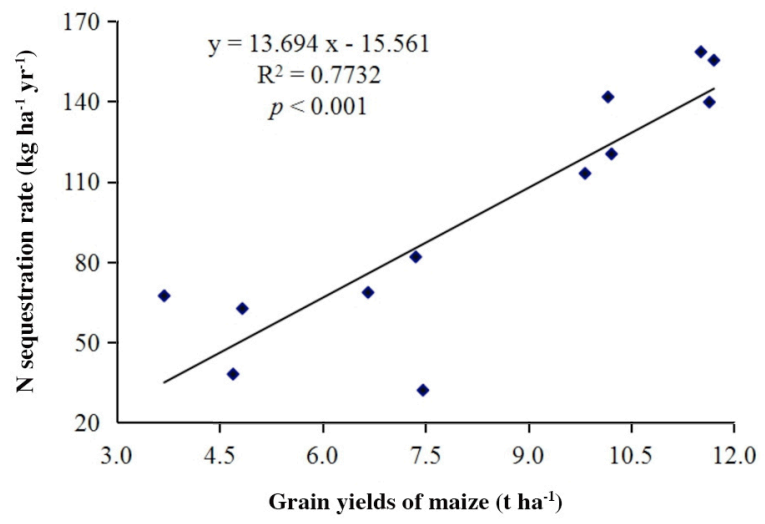

DISCUSSION

\section{Soil organic $\mathbf{C}$ and total $\mathbf{N}$}

Soil organic $\mathrm{C}$ and total $\mathrm{N}$ content in two compost treatments were significantly increased than in the chemical fertilizer and control treatments and initial values, as was similar to the other study (Chu et al., 2007). This manifested that increment of SOC and total $\mathrm{N}$ is more distinct in organic fertilizer treatments than in inorganic fertilizer treatments. This reason was that there had an addition of organic $\mathrm{C}$ incorporated into soil in organic fertilizer treatments. Soil organic $\mathrm{C}$ and total $\mathrm{N}$ contents were only slightly higher in chemical fertilizer treatment than in the control treatment, which was consistent with the previous reports (Su et al., 2006). Nevertheless, Zhong and Cai (2007) in a paddy soil derived from quaternary red clay and Mandal et al. (2007) in Inceptisol of India found that SOC C and total N content were significantly higher in the chemical fertilizer treatment compared with unfertilized treatment. The possible reason was that there had great crop residues in the chemical fertilizer treatment than in control treatment.

Soil organic C and total $\mathrm{N}$ content were higher in control treatment than in initial values, and Shen et al. (2007) and $\mathrm{Bi}$ et al. (2009) reported similar results in double rice cropping systems or in rice-wheat agroecosystem of 
China. Similarly, Kundu et al. (2007b) also reported that SOC and total N content were significantly increased in the control treatment compared to the initial values in a sandy loam soil of the Indian Himalayas after $30 \mathrm{yr}$ of cropping. Soil organic $\mathrm{C}$ contents marginally improved from the start of the experiment in the unfertilized control plots due to the addition of $\mathrm{C}$ from the crop stubbles and roots, higher humification rate, and lower decay rate (Kundu et al., 2007b). Kundu et al. (2007a) reported that $26 \%$ of the added crop biomass $C$ was annually humified from humus into soil and the increase in SOC concentrations.

Our result showed that application of compost or chemical fertilizer including unfertilized treatment could increase SOC stock, and average the SOC stock was increased by $9.98 \mathrm{t} \mathrm{ha}^{-1}(0-20 \mathrm{~cm})$ in the $11 \mathrm{yr}$ period, which indicated potential for organic $\mathrm{C}$ sequestration in upland soils (Fan et al., 2008). This result was similar to the other longterm fertilizer experiment site reported by Zhou et al. (2013), who found that SOC stock in all treatments showed increasing trends, including the control treatment in a semi-arid cropland of the Loess Plateau region. However, an average SOC loss of $5.82 \mathrm{t} \mathrm{ha}^{-1}(0-20 \mathrm{~cm})$ in inorganic fertilizers alone treatments was observed over the $23 \mathrm{yr}$ period in the arid region of northwest China, but long-term application of manure alone or combined with inorganic fertilizers could evenly sequestrate SOC of $5.90 \mathrm{t} \mathrm{ha}^{-1}$ in the $23 \mathrm{yr}$ period $(0-20 \mathrm{~cm})(\mathrm{Su}$ et al., 2006). Soil organic $\mathrm{C}$ sequestration $\left(0-20 \mathrm{~cm}\right.$ ) was $5.81 \mathrm{t} \mathrm{ha}^{-1}$ in inorganic fertilizer treatment, but was $14.33-15.35 \mathrm{t} \mathrm{ha}^{-1}$ in compost treatments through the $11 \mathrm{yr}$ period in the present study. This manifested that application of compost have strongly promoted SOC accumulation because compost was addition $\mathrm{C}$ resources incorporated into soils (Chakraborty et al., 2011). At the same time, crop biomass in compost treatments was higher than in inorganic fertilizer treatment; correspondingly, crop residue (including crop stubble and root biomass) also were higher in compost treatments than in inorganic fertilizer treatment (Kundu et al., 2007a; Gong et al., 2011). The soil organic $\mathrm{C}$ sequestration rate (0-20 cm) was 0.40-1.40 $\mathrm{tha}^{-1} \mathrm{yr}^{-1}$ in this experiment (average $\left.0.91 \mathrm{tha}^{-1} \mathrm{yr}^{-1}\right)$; however, soil organic $\mathrm{C}$ sequestration rate was only 0.16-0.42 $\mathrm{t} \mathrm{ha}^{-1} \mathrm{yr}^{-1}$ after application of farmyard manure in an arid region of northwest China (Su et al., 2006). In contrast to the other long-term experiment sites, SOC sequestration rate was only $0.15-0.51 \mathrm{tha}^{-1} \mathrm{yr}^{-1}$ (0-20 cm) in Belle Mina, Alabama, southeastern USA (Sainju et al., 2008), was 0.04-0.16 $\mathrm{t} \mathrm{ha}^{-1} \mathrm{yr}^{-1}$ in an Inceptisol in south-eastern Norway (Holeplass et al., 2004). Soil organic C sequestration was significantly positively correlated with grain yields of maize. Generally, high crop grain yields corresponded high crop residues (including roots and stubbles), and high crop residues were closely associated with high SOC storages.

Soil total $\mathrm{N}$ stock $(0-20 \mathrm{~cm})$ in all treatments was increased by $0.62-1.66 \mathrm{t} \mathrm{ha}^{-1}$ in the $11 \mathrm{yr}$ period. Sainju et al. (2008) reported that soil total $\mathrm{N}$ stock $(0-20 \mathrm{~cm})$ was increased by $0.15-0.49 \mathrm{t} \mathrm{ha}^{-1}$ in the $10 \mathrm{yr}$ period in southeastern USA. Soil total $\mathrm{N}$ sequestration rate was significantly higher in two compost treatments than in the chemical fertilizer and control treatments. Similarly, Gami et al. (2009) observed that soil total N stock was significantly higher in farmyard manure treatment than in NPK and unfertilized treatments in Nepal. Gong et al. (2011) revealed that soil organic $\mathrm{N}$ sequestration was significantly higher in organic fertilizer treatment than in inorganic fertilizer treatment and control in the North China Plain. However, an average soil total $\mathrm{N}$ loss of $0.25 \mathrm{t} \mathrm{ha}^{-1}(0-20 \mathrm{~cm})$ in inorganic fertilizers alone treatments was observed over the $27 \mathrm{yr}$ period in the Loess Plateau region of northwest China, and soil total $\mathrm{N}$ were sequestrated when long-term application of manure alone or combined with inorganic fertilizers (Zhou et al., 2013).

\section{Soil nutrients, soil pH and bulk density}

The content of available $\mathrm{N}$ in compost treatments was significantly higher than in the chemical fertilizer and control treatments, and there had nonsignificant difference between chemical fertilizer and control treatment, and Bi et al. (2009) reported consistent with results. Nevertheless, Shen et al. (2007) found that available N content in the manure and chemical fertilizer treatments was significantly higher than in the control treatment. The content of available $\mathrm{N}$ in compost treatments was significantly higher than initial values, and $\mathrm{Bi}$ et al. (2009) also observed similar result in Jinxian experimental site. The content of available P was significantly increased due to long-term fertilization compared with the control. Similarly, Liu et al. (2010) found that available P content in manure and chemical fertilizer treatments was significantly higher than in the control treatment. The content of available P in the EM compost treatment was significantly higher than in chemical fertilizer treatment and consistent result reported by Chu et al. (2007). However, Lee et al. (2009) reported that available P content in NPK fertilizer treatment 
was significantly higher than in the compost treatment. Soil available P content was significantly decreased in control treatment compared with initial values. Similarly, Kundu et al. (2007b) and Lv et al. (2011) also reported that available P content in long-term unfertilized soil was decreased. However, Singh et al. (2007) observed that available $\mathrm{P}$ content in $8 \mathrm{yr}$ unfertilized Vertisol in India was increased. The available K content was significantly higher in the compost treatment than in the chemical fertilizer and control treatment and initial values, and Liu et al. (2010) reported consistent with results. However, Shen et al. (2007) reported that available K content was significantly decreased in the manure and chemical fertilizer treatments including control treatment compared to initial values, and $\mathrm{He}$ et al. (2012) found that available K content in the chemical fertilizer and control treatments was lower than initial values. The concentration of available $\mathrm{P}$ and $\mathrm{K}$ was significantly higher in the EM compost treatment than in the traditional compost treatment, which revealed that the effect of improved soil fertility with EM compost was better compared with traditional compost. This was because there are many advantageous microbes in EM compost, which accelerated release of plant-available nutrients from soil.

Soil pH in fertilization treatments was significantly decreased than in control treatment (Chu et al., 2007). Soil pH in two compost treatments was significantly lower than in the chemical fertilizer treatment, which was contrasted to the result reported by Liu et al. (2010). Soil pH in all treatment was significantly decreased than initial values. Similarly, application of fertilizer decreased soil pH (Hao et al., 2008). However, soil pH in the topsoil rose from 5.2 to 6.0 in the West African Sahel irrigated rice within 4 yr fertilization and remained stable thereafter (Haefele et al., 2004). Application of the compost caused increases in soil $\mathrm{pH}$, with a slight reduction noted for NPK treatment in Ireland (Courtney and Mullen, 2008).

Soil bulk density was significantly lower in two compost treatments than in the control treatment, as was consistent with the other report (Gami et al., 2009); however, it was contrasted to the result of Nayak et al. (2012). Rasool et al. (2007) observed that soil bulk density was significantly decreased in organic fertilizer treatments, but there had nonsignificant difference between chemical fertilizer and control treatment in paddy field, as was consistent with our results. Gong et al. (2009) found that soil bulk density was significantly decreased due to longterm application of manure or chemical fertilizer, and soil bulk density in the manure treatment was significantly lower than in the chemical fertilizer treatment.

\section{Maize yields}

Maize plant height was increased due to long-term fertilization, which was consistent with the reported by Hu and Qi (2013), who found that long-term application of organic or inorganic fertilizer enhanced wheat plant height. Maize grains per spike and thousand grains weight were significantly increased due to long-term soil amendments. Haefele et al. (2002) observed that long-term application fertilizer significantly increased grains per spike and thousand grains weight of rice 'Jaya'. In contrast, Surekha et al. (2010) reported that thousand grains weight of rice was not influenced by fertilization. Kato and Yamagishi (2011) found that thousand grains weight of wheat in the manure treatment was lower than in inorganic fertilizer treatment, which was contrasted to our results. Maize grains per spike and thousand grains weight were significantly increased due to EM application in the present study. Similarly, hundred grains weight of vigna were significantly increased due to EM application in farmyard manure and crop residues amended soils (Javaid and Bajwa, 2011a).

Maize grain yields were significantly increased due to long-term application of compost or chemical fertilizer. Similarly, maize grain yields in the chemical fertilizer treatment were significantly higher than in the control treatment (He et al., 2012), and maize grain yields were significantly increased due to long-term application of farmyard manure and chemical fertilizer (Liu et al., 2010). Mugwira et al. (2002) also found that application of manure significantly increased maize grain yields. Maize grain yields in two compost treatment were significantly higher than in the chemical fertilizer treatment, as was consistent with the result reported by Rasool et al. (2008), who found that maize grain yields in the farmyard manure treatment were significantly higher than in the chemical fertilizer treatment. Similarly, average rice and wheat grain yields in the farmyard manure treatment were significantly higher than in the chemical fertilizer treatment in $20 \mathrm{yr}$ fertilizer experiment of Nepal.

Maize grain yields in the EM compost treatment were significantly higher than in the traditional compost treatment. These results were similar to the previous studies. For example, wheat and rice grain yields were increased when EM combined with manure or chemical fertilizer was applied. Soybean and mung-bean grain yields were significantly 
increased due to EM application in farmyard manure amendment soils (Javaid and Bajwa, 2011b). Grain yields of rice were enhanced by $46 \%$ due to EM application in the green manure amended soils. The vigna grain yields increased by $24 \%, 15 \%$, and $84 \%$ when application of EM in combination with farmyard manure, crop residues or NPK fertilizer compared with corresponding treatments without EM application, respectively (Javaid and Bajwa, 2011a). The higher crop yields in EM in combination with organic materials amended soils could be attributed largely to the activity of the introduced exotic beneficial microorganism, which stimulated the decomposition of organic materials and the release of nutrients for plant uptake (Javaid and Bajwa, 2011b).

\section{CONCLUSIONS}

Based on these results, we concluded that long-term repeated application of effective microorganism (EM) compost significantly promoted soil $\mathrm{C}$ and $\mathrm{N}$ sequestration, increased soil nutrients, and decreased soil $\mathrm{pH}$ and bulk density. Therefore, we concluded that long-term application of manure could increase soil $\mathrm{C}$ and $\mathrm{N}$ storages, protect soil environment, improve soil fertility, and enhance crop yields contrasted to application of inorganic fertilizers. Moreover, the results also revealed that the effect of improving soil fertility and enhanced crop yields in application of compost appending EM was better than alone application of compost.

\section{ACKNOWLEDGEMENTS}

The Project Sponsored by the National Key Research and Development Program of China (2016YFD0200100); the Special Fund for Agro-scientific Research in the Public Interest of China (201203030); the Scientific Research Foundation for the Returned Overseas Chinese Scholars, State Education Ministry (2012-940); the Scientific and Technological Key Achievements Cultivation Project of Hubei Academy of Agricultural Sciences (2017CGPY01) and the National Natural Science Foundation of China (31300442).

\section{REFERENCES}

Bi, L.D., Zhang, B., Liu, G.R., Li, Z.Z., Liu, Y.R., Ye, C., et al. 2009. Long-term effects of organic amendments on the rice yields for double rice cropping systems in subtropical China. Agriculture, Ecosystems and Environment 129:534-541.

Chakraborty, A., Chakrabarti, K., Chakraborty, A., and Ghosh, S. 2011. Effect of long-term fertilizers and manure application on microbial biomass and microbial activity of a tropical agricultural soil. Biology and Fertility of Soils 47:227-233.

Chu, H., Lin, X., Fujii, T., Morimoto, S., Yagi, K., Hu, J., et al. 2007. Soil microbial biomass, dehydrogenase activity, bacterial community structure in response to long-term fertilizer management. Soil Biology and Biochemistry 39:2971-2976.

Courtney, R.G., and Mullen G.J. 2008. Soil quality and barley growth as influenced by the land application of two compost types. Bioresource Technology 99:2913-2918.

Fan, T.L., Xu, M.G., Song, S.Y., Zhou, G.Y., and Ding, L.P. 2008. Trends in grain yields and soil organic C in a long-term fertilization experiment in the China Loess Plateau. Journal of Plant Nutrition and Soil Science 171:448-457.

Gami, S.K., Lauren, J.G., and Duxbury, J.M. 2009. Soil organic carbon and nitrogen stocks in Nepal long-term soil fertility experiments. Soil and Tillage Research 106:95-103.

Gong, W, Yan, X.Y., Wang, J.Y., Hu, T.X., and Gong, Y.B. 2009. Long-term manuring and fertilization effects on soil organic carbon pools under a wheat-maize cropping system in North China Plain. Plant and Soil 314:67-76.

Gong, W., Yan, X.Y., Wang, J.Y., Hu, T.X., and Gong, Y.B. 2011. Long-term applications of chemical and organic fertilizers on plant-available nitrogen pools and nitrogen management index. Biology and Fertility of Soils 47:767-775.

Haefele, S.M., Wopereis, M.C.S., Schloebohmc, A.-M., and Wiechmann, H. 2004. Long-term fertility experiments for irrigated rice in the West African Sahel: Effect on soil characteristics. Field Crops Research 85:61-77.

Haefele, S.M., Wopereis, M.C.S., and Wiechmann, H. 2002. Long-term fertility experiments for irrigated rice in the West African Sahel: Agronomic results. Field Crops Research 78:119-131.

Hao, X.H., Liu, S.L., Wu, J.S., Hu, R.G., Tong, C.L., and Su Y.Y. 2008. Effect of long-term application of inorganic fertilizer and organic amendments on soil organic matter and microbial biomass in three subtropical paddy soils. Nutrient Cycling in Agroecosystems 81:17-24.

He, C.E., Ouyang, Z., Tian, Z.R., and Schaffer, H.D. 2012. Yield and potassium balance in a wheat-maize cropping system of the North China Plain. Agronomy Journal 104:1016-1022. 
Higa, T., 1991. Effective microorganisms: A biotechnology for mankind. p. 8-14. In Parr, J.F., Hornick, S.B., Whitman, C.E. (eds.) Proceedings of $1^{\text {st }}$ Kyusei Nature Farming, Khon Kaen, Thailand. 17-21 October 1989. USDA, Washington, D.C., USA.

Holeplass, H., Singh, B.R., and Lal, R. 2004. Carbon sequestration in soil aggregates under different crop rotations and nitrogen fertilization in an Inceptisol in south-eastern Norway. Nutrient Cycling in Agroecosystems 70:167-177.

Hu, C., and Qi, Y.C. 2013. Long-term effective microorganisms application promote growth and increase yields and nutrition of wheat in China. European Journal of Agronomy 46:63-67.

Javaid, A., and Bajwa, R. 2011a. Effect of effective microorganism application on crop growth, yield, and nutrition in Vigna radiata (L.) Wilczek in different soil amendment systems. Communications in Soil Science and Plant Analysis 42:2112-2121.

Javaid, A., and Bajwa, R. 2011b. Field evaluation of effective microorganisms (EM) application for growth, nodulation, and nutrition of mung bean. Turkish Journal of Agriculture and Forestry 35:443-452.

Kato, Y., and Yamagishi, J. 2011. Long-term effects of organic manure application on the productivity of winter wheat grown in a crop rotation with maize in Japan. Field Crop Research 120:387-395.

Kundu, S., Bhattacharyya, R., Prakash, V., Ghosh, B.N., and Gupta, H.S. 2007a. Carbon sequestration and relationship between carbon addition and storage under rainfed soybean-wheat rotation in a sandy loam soil of the Indian Himalayas. Soil and Tillage Research 92:87-95.

Kundu, S., Bhattacharyya, R., Prakash, V., Gupta, H.S., Pathak, H., and Ladha, J.K. 2007b. Long-term yield trend and sustainability of rainfed soybean-wheat system through farmyard manure application in a sandy loam soil of the Indian Himalayas. Biology and Fertility of Soils 43:271-280.

Lee, S.B., Lee, C.H., Jung, K.Y., Park, K.D., Lee, D., and Kim, P.J. 2009. Changes of soil organic carbon and its fractions in relation to soil physical properties in a long-term fertilized paddy. Soil and Tillage Research 104:227-232.

Liu, E.K., Yan, C.R., Mei, X.R., He, W.Q., Bing, S.H., Ding, L.P., et al. 2010. Long-term effect of chemical fertilizer, straw, and manure on soil chemical and biological properties in northwest China. Geoderma 158:173-180.

Lv, M.R., Li, Z.P., Che, Y.P., Han, F.X., and Liu, M. 2011. Soil organic C, nutrients, microbial biomass, and grain yield of rice (Oryza sativa L.) after 18 years of fertilizer application to an infertile paddy soil. Biology and Fertility of Soils 47:777-783.

Mandal, A., Patra, A.K., Singh, D., Swarup, A., and Masto, R.E. 2007. Effect of long-term application of manure and fertilizer on biological and biochemical activities in soil during crop development stages. Bioresource Technology 98:3585-3592.

Mugwira, L.M., Nyamangara, J., and Hikwa, D. 2002. Effects of manure and fertilizer on maize at a research station and in a smallholder (peasant) area of Zimbabwe. Communications in Soil Science and Plant Analysis 33:379-402.

Nayak, A.K., Gangwar, B., Shukla, A.K., Mazumdar, S.P., Kumar, A., Raja, R., et al. 2012. Long-term effect of different integrated nutrient management on soil organic carbon and its fractions and sustainability of rice-wheat system in Indo Gangetic Plains of India. Field Crops Research 127:129-139.

Rasool, R., Kukal, S.S., and Hira, G.S. 2007. Soil physical fertility and crop performance as affected by long term application of FYM and inorganic fertilizers in rice-wheat system. Soil and Tillage Research 96:64-72.

Rasool, R., Kukal, S.S., and Hira, G.S. 2008. Soil organic carbon and physical properties as affected by long-term application of FYM and inorganic fertilizers in maize-wheat system. Soil and Tillage Research 101:31-36.

Sainju, U.M., Senwo, Z.N., Nyakatawa, E.Z., Tazisong, I.A., and Reddy, K.C. 2008. Soil carbon and nitrogen sequestration as affected by long-term tillage, cropping systems, and nitrogen fertilizer sources. Agriculture, Ecosystems and Environment 127:234-240.

Shen, M.X., Yang, L.Z., Yao, Y.M., Wu, D.D., Wang, J.G., Guo, R.L., et al. 2007. Long-term effects of fertilizer managements on crop yields and organic carbon storage of a typical rice-wheat agroecosystem of China. Biology and Fertility of Soils 44:187-200.

Singh, M., Reddy, K.S., Singh, V.P., and Rupa, T.R. 2007. Phosphorus availability to rice (Oriza sativa L.)-wheat (Triticum aestivum L.) in a Vertisol after eight years of inorganic and organic fertilizer additions. Bioresource Technology 98:1474-1481.

Su, Y.Z., Wang, F., Suo, D.R., Zhang, Z.H., and Du, M.W. 2006. Long-term effect of fertilizer and manure application on soil carbon sequestration and soil fertility under the wheat-wheat-maize cropping system in northwest China. Nutrient Cycling in Agroecosystems 75:285-295.

Surekha, K., Latha, P.C., Rao, K.V., and Kumar, R.M. 2010. Grain yield, yield components, soil fertility, and biological activity under organic and conventional rice production systems. Communications in Soil Science and Plant Analysis 41:2279-2292.

Zhong, W.H., and Cai, Z.C. 2007. Long-term effects of inorganic fertilizers on microbial biomass and community functional diversity in a paddy soil derived from quaternary red clay. Applied Soil Ecology 36:84-91.

Zhou, Z.C., Gan, Z.T., Shangguan, Z.P., and Zhang, F.P. 2013. Effects of long-term repeated mineral and organic fertilizer applications on soil organic carbon and total nitrogen in a semi-arid cropland. European Journal of Agronomy 45:20-26. 